Progress in Physical Geography 33(3) (2009) pp. 319-338

\title{
0
}

\section{Impacts of alien plant invasions on species richness in Mediterranean-type ecosystems: a meta-analysis}

\author{
Mirijam Gaertner,* Alana Den Breeyen, \\ Cang Hui and David M. Richardson
}

Centre for Invasion Biology, Department of Botany and Zoology, Stellenbosch University, Private Bag X1, Matieland 7602, South Africa

\begin{abstract}
Besides a general consensus regarding the negative impact of invasive alien species in the literature, only recently has the decline of native species attributable to biological invasions begun to be quantified in many parts of the world. The cause-effect relationship between the establishment and proliferation of alien species and the extinction of native species is, however, seldom demonstrated. We conducted a meta-analysis of studies in Mediterranean-type ecosystems (MTEs) to examine: (1) whether invasion of alien plant species indeed causes a reduction in the number of native plant species at different spatial and temporal scales; (2) which growth forms, habitat types and areas are most affected by invasions; and (3) which taxa are most responsible for native species richness declines. Our results confirm a significant decline in native species richness attributable to alien invasions. Studies conducted at small scales or sampled over long periods reveal stronger impacts of alien invasion than those at large spatial scales and over short periods. Alien species from regions with similar climates have much stronger impacts, with the native species richness in South Africa and Australia declining significantly more post-invasion than for European sites. Australian Acacia species in South Africa accounted for the most significant declines in native species richness. Among the different growth forms of alien plants, annual herbs, trees and creepers had the greatest impact, whereas graminoids generally caused insignificant changes to the native community. Native species richness of shrublands, old fields and dune vegetation showed significant declines, in contrast to insignificant declines for forest habitats.
\end{abstract}

Key words: biodiversity, biological invasions, exotic species, growth form, habitat type, spatial and temporal scale.

\section{Introduction}

Invasive alien species are considered a threat to biodiversity and ecosystem stability, and are widely held to be responsible for the decline of native species richness and the local extinction of certain species (Richardson

*Author for correspondence. Email: gaertnem@sun.ac.za

(C) The Author(s), 2009. Reprints and permissions:

DOI: $10.1177 / 0309133309341607$

http://www.sagepub.co.uk/journalsPermissions.nav 
etal., 1989; Wilcove et al., 1998; Davis, 2003). However, it is often difficult to demonstrate the cause-effect relationship between the establishment and proliferation of alien plant species and the extinction of native species (Brown and Sax, 2004; Davis, 2009). Recently, the broadly accepted connection between invasive species and native diversity declines has been debated (Houlahan and Findlay, 2004; Hejda and Pyšek, 2006; Richardson et al., 2007). Perceptions on the negative impacts of invasions on native plant communities are, to a certain degree, affected by the spatial scales of studies. This has been widely recognized in the discussion about the 'invasion paradox' which describes the co-occurrence of independent lines of support for both a negative and a positive relationship between native biodiversity and the invasions of invasive alien species depending on the spatial scale of investigation (Fridley et al., 2007). Another factor which must be considered when evaluating impacts of alien invasions on native species richness is the different timescales involved in invasions and extinctions (Sax et al., 2002; Richardson et al., 2007). Although some species may be doomed to extinction due to disruptions caused by invasions (eg, Traveset and Richardson, 2006), extinction can be delayed (Tilman et al., 1994). With plant species especially, the process of extinction takes much longer (decades or longer) than naturalizations or invasion (rates easily measured in years). It is likely that many plant species will eventually be driven to extinction as a direct consequence of current processes. Therefore, we would expect a stronger signal of negative impact of invasions from studies that capture effects over longer periods. It is also important to consider that although invasions of alien species may not result in extinctions of entire species (over the typically short timescale captured in a field study) this does not mean that they are not reducing biodiversity. They may still be causing declines in the abundance of native species or the elimination of some populations which may reduce genetic diversity (Davis, 2009). Nevertheless, the above generalizations have emerged from isolated case studies and it is difficult to synthesize results from different spatial and temporal scales. Besides these scale-effects on the observed impact of alien invasions, features of the invading species and the invaded habitat must also be taken into account when considering the impact of alien invasions on native species richness.

We investigated how different spatial and temporal scales and factors (such as taxa, growth forms, habitat types and countries) affect the impact of invasions on native species richness. We chose to study the impact of invasions on native species richness in Mediterranean-type ecosystems (MTEs) which have similar climates and other environmental drivers. Several studies have addressed the importance of comparing alien plant invasions in similar climatic regions (Kruger et al., 1989; Sax, 2002; Pauchard et al., 2004), as comparing ecosystems with widely diverging climates, disturbance regimes and other factors may reduce our ability to isolate the effects of particular stressors. Mediterranean-climate zones are considered to be especially appropriate for global-scale 'natural experiments' as they differ less in key aspects than other biome types that occur at multiple localities around the world, eg, savannas (Pauchard et al., 2004). Invasions in MTEs have been well studied for decades (Groves and Di Castri, 1991; Richardson et al., 1992; Rejmánek and Randall, 1994) and the problem of alien plant invasions is widely recognized as a major threat to biodiversity in all MTEs today (Rejmánek and Randall, 1994; Rouget et al., 2003; Seabloom et al., 2006; Underwood et al., 2009).

We conducted a meta-analysis to quantify the impact of alien invasion on native plant species richness. This approach allowed us to examine: (1) whether invasion of alien plant species indeed causes a reduction in the number of native plant species at different localities and at different spatial and temporal scales; (2) which growth forms, habitat types 
and areas are most affected by invasions; and (3) which taxa are most responsible for native species richness declines.

\section{Methods}

\section{Mediterranean-type ecosystems}

Mediterranean-type ecosystems (MTEs) are found between latitudes $32^{\circ}$ and $40^{\circ}$ north and south of the equator on the west coast of continents in five regions of the world, namely South Africa, Australia, California, Chile and the Mediterranean Basin (Aschmann, 1973). The defining factors for the Mediterraneantype climate are summer drought and winter rainfall (Köppen, 1923). Annual rainfall ranges from below $90 \mathrm{~mm}$ to $1500 \mathrm{~mm}$; annual mean temperature ranges from about $11^{\circ} \mathrm{C}$ to $17^{\circ} \mathrm{C}$; mean seasonal temperatures are $8^{\circ} \mathrm{C}$ in the coldest month and up to $25^{\circ} \mathrm{C}$ in the hottest month (Aschmann, 1973). The vegetation of MTEs is characterized by chaparral-like shrublands, coastal scrub, woodland and forest (Dallman, 1998). MTEs have remarkable plant diversity. Covering less than $5 \%$ of the Earth's surface, they contain nearly $20 \%$ of the planet's known plant species (Cowling et al., 1996).

\section{Data}

We confined our search to MTEs in five regions covering South Africa, Australia, Europe, California and Chile. The first criterion for our literature search was that the focus of the study should be an invasive plant species alien to the area under investigation (sensu Richardson et al., 2000; sensu Pyšek et al., 2004). Second, we only included studies that directly compared invaded ecosystems dominated by invasive alien species with corresponding, relatively intact, ecosystems in terms of native species richness. Third, we also required that species richness was quantified (or where this could be computed from presented data) as mean number of native species with standard error (SE) and sample size. In some cases, where such data were not provided, we obtained the data from the authors.

We searched for papers using combinations of the terms 'exotic', 'invasive', 'invasion', 'alien species', 'species richness' and 'biodiversity' on 'Web of Science', 'JSTOR' and 'Google Scholar'. Additional literature was obtained through conventional searches of the bibliographies of papers and reports. We did not limit the review to papers in a set of journals published during a certain period. This method allowed us to include a wider range of literature than if we had limited the survey to only certain journals or a certain timeframe.

\section{Analysis}

We summarized data from all the studies that fulfilled our criteria in a table including information about study area and habitat, origin and growth form of the invading species, and temporal and spatial scale, defined by extent of study area and unit size (grain) (Table 1). Eleven studies (three from South Africa, four from Europe, three from California and one from Australia) including 24 species (Figure 1) met our criteria. Some studies investigated species at different sites and in different seasons this left us with 47 cases for the meta-analysis. Chile was not included in the meta-analysis at all as none of the studies met our criteria.

For the meta-analysis, we recorded the number of native species (mean and SE) in invaded and natural reference sites for each study. The meta-analysis is a technique of quantitative research synthesis (Smith and Glass, 1977) and has been widely used in ecology (eg, Ashton et al., 2005). In this study, we used the comprehensive meta-analysis software (CMA version 2.0; Borenstein et al., 2005) to conduct a twogroup comparison (native versus invaded) with additional moderators as defined by, for example, taxa, temporal scale, spatial scale, growth form, habitat, origin or invaded country. Cohen's (1988) mean difference 


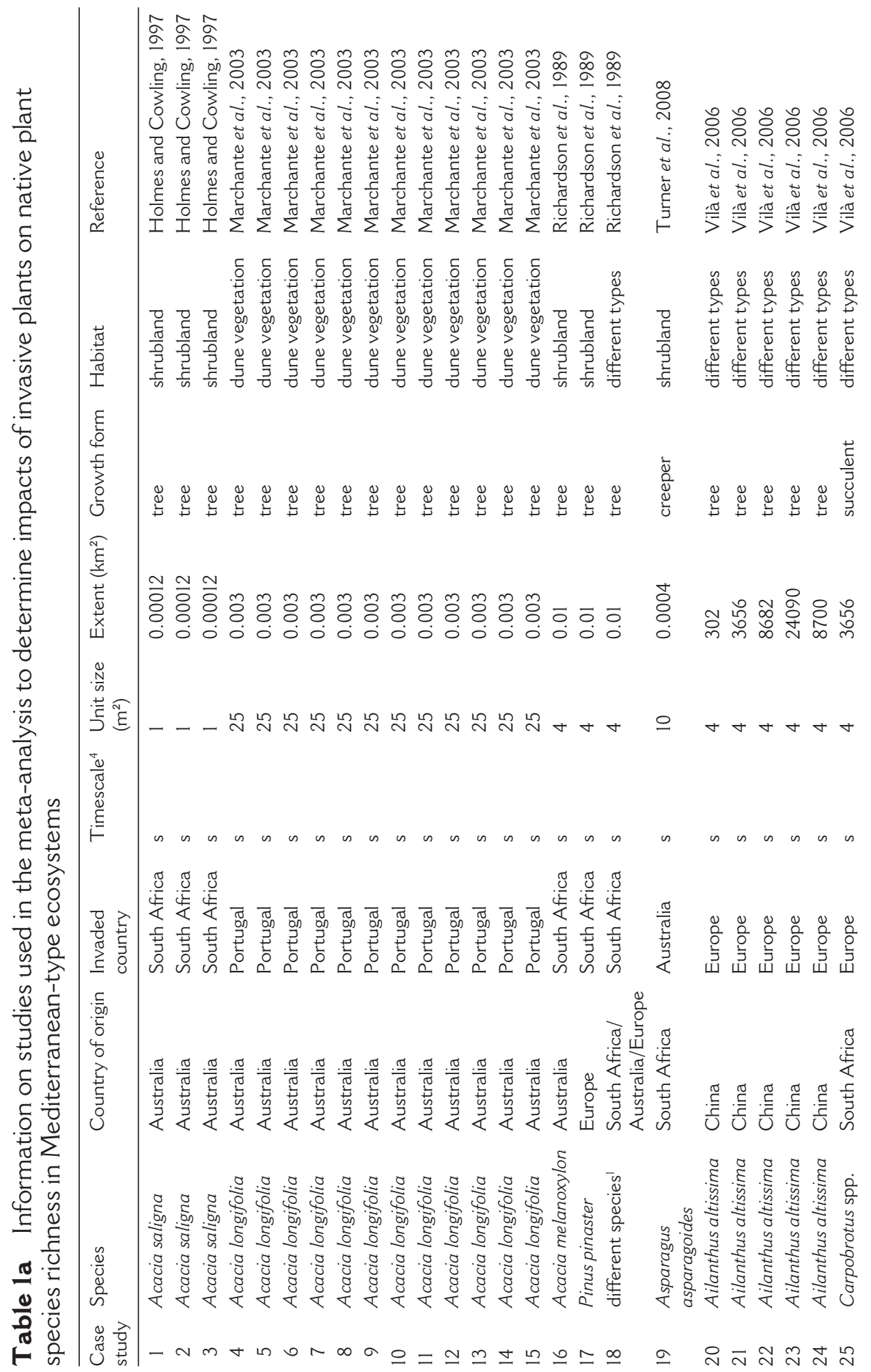




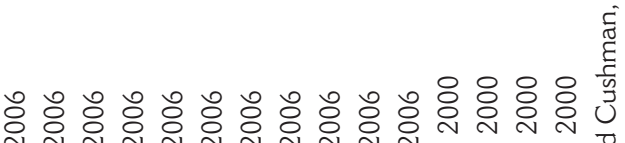

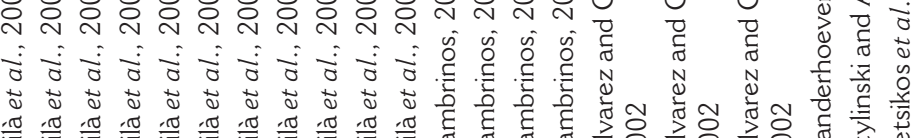

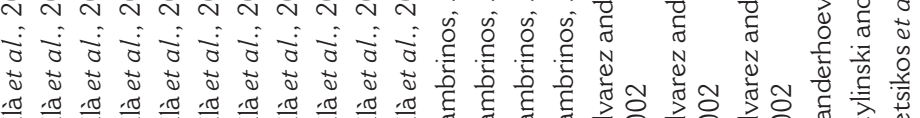

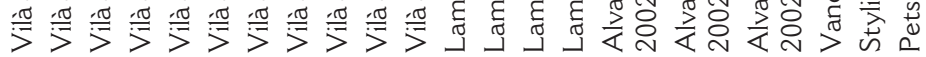

\&

$\begin{array}{lll} & \\ 0 & \end{array}$

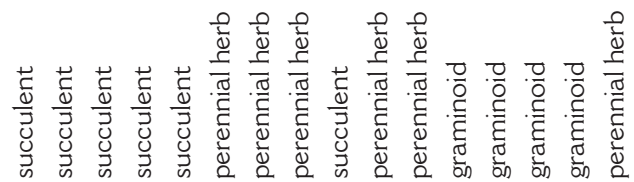

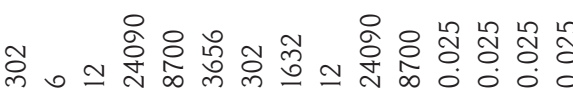

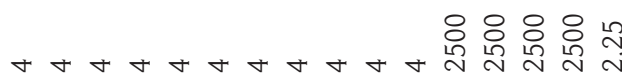

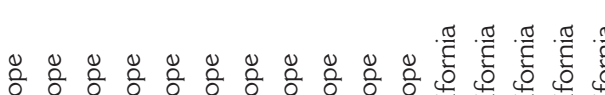

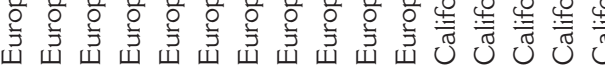

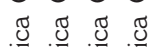
g.

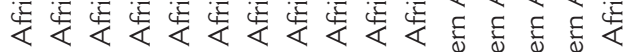

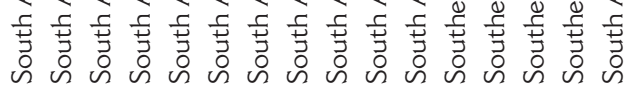

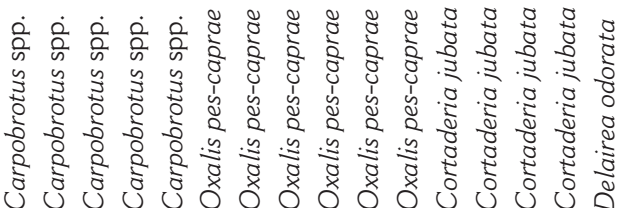

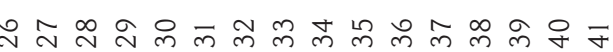
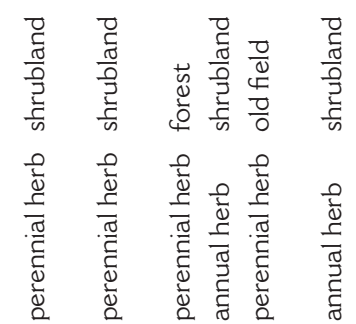

กู่

0
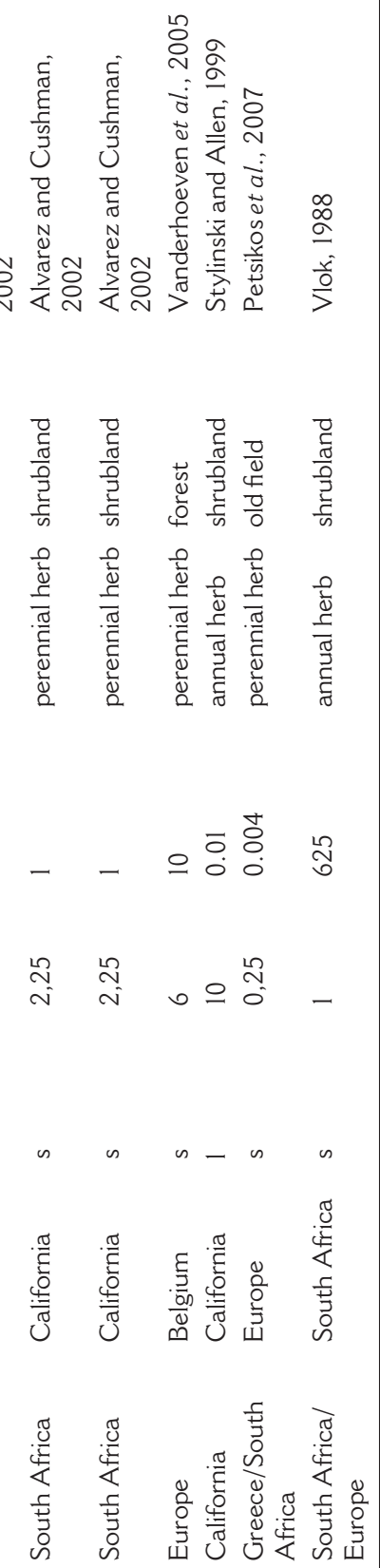

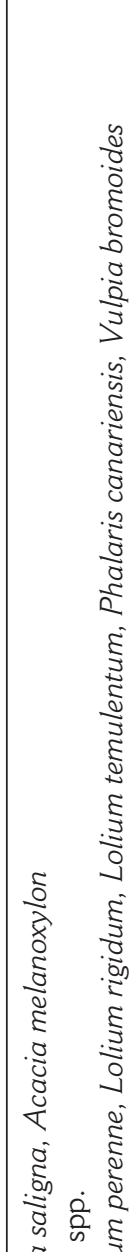
के के ह

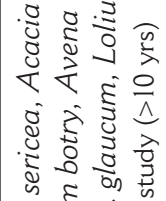
\&ँ

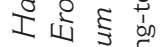
ơ 0
0
0 C. ह ह

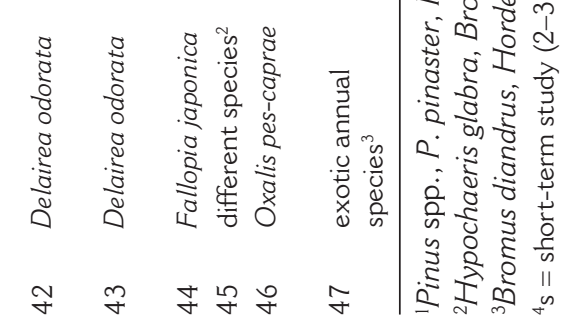




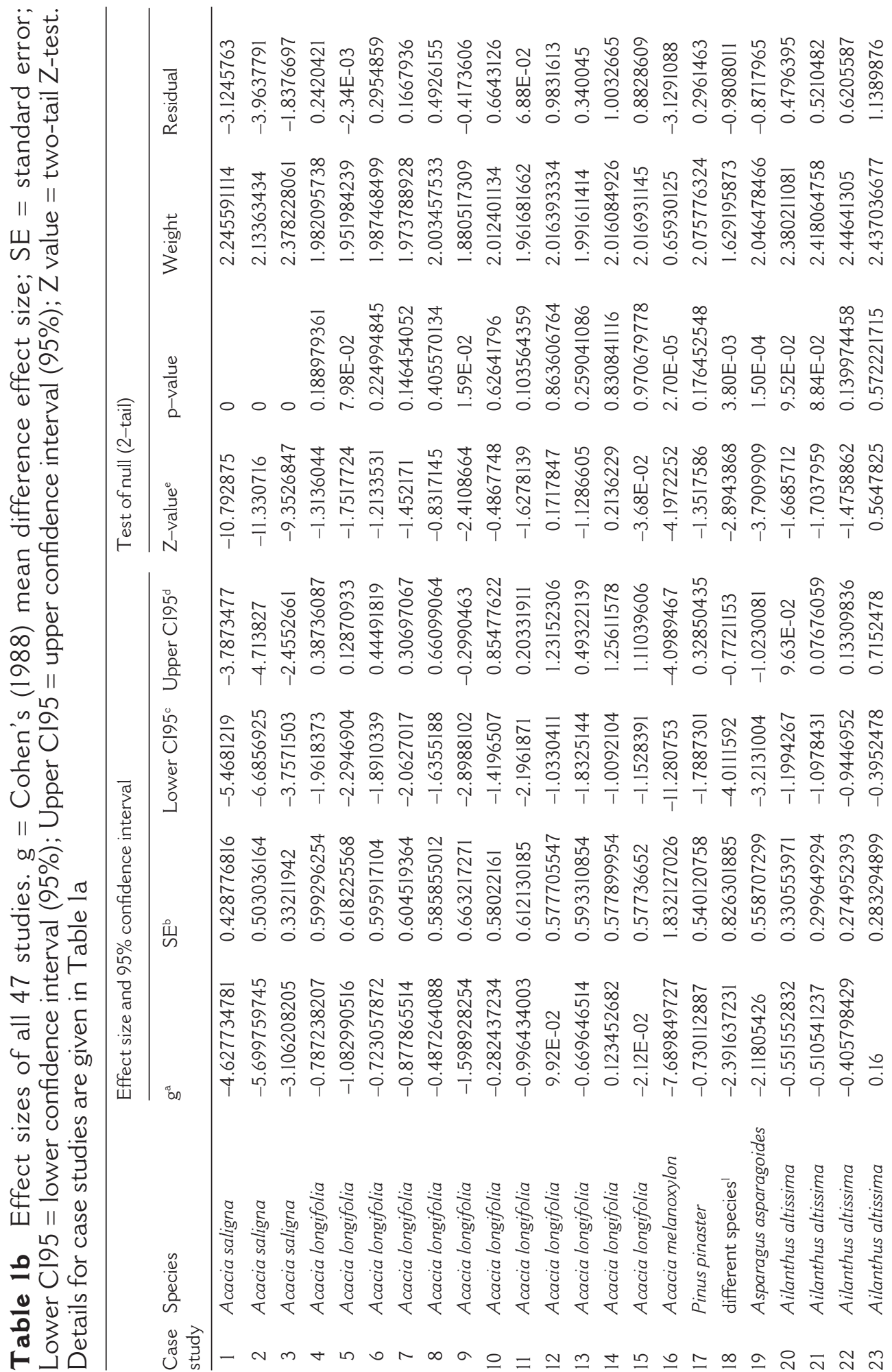




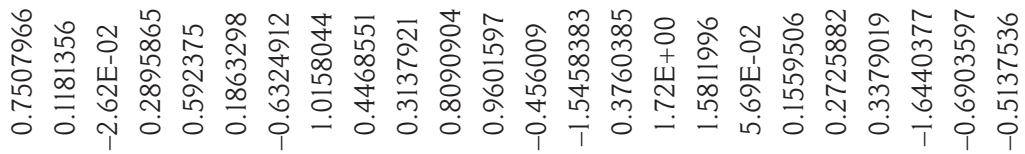

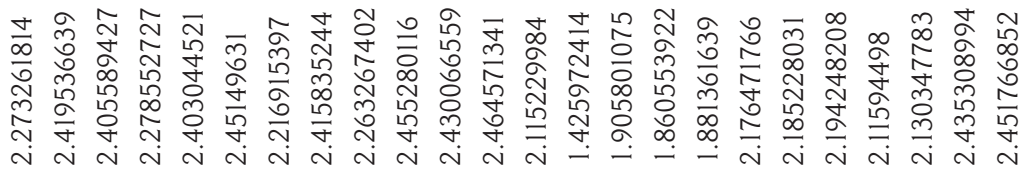

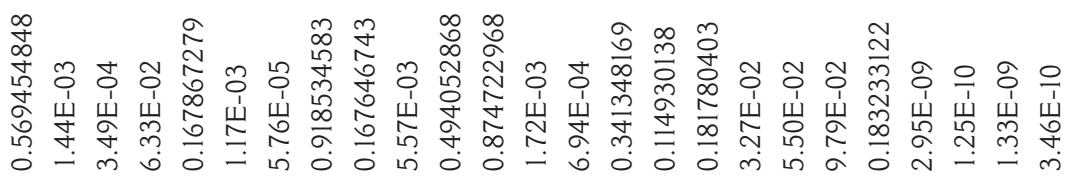

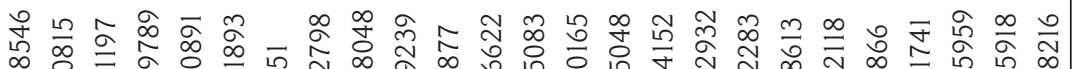

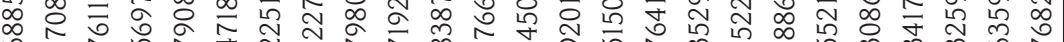

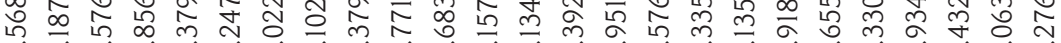
i pंi

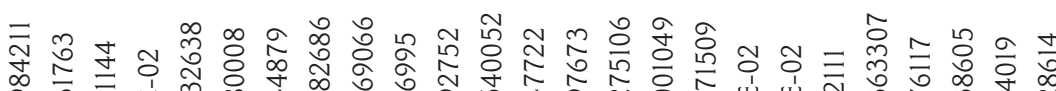

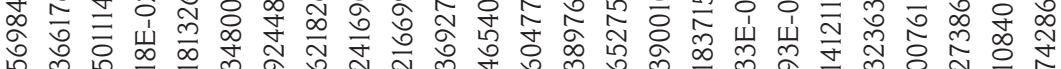

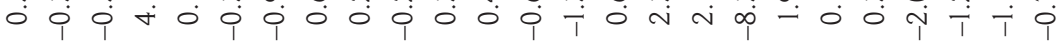

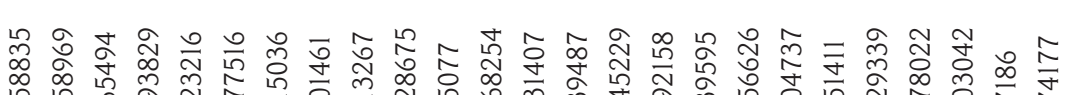

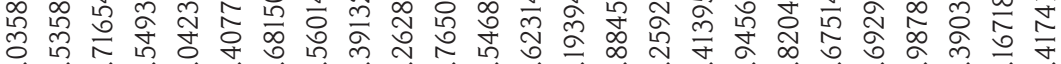

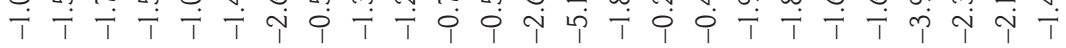

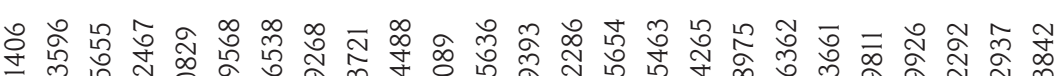

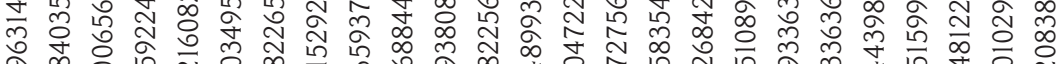
o.

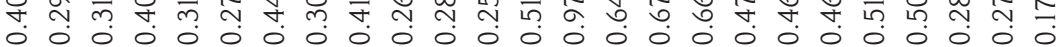

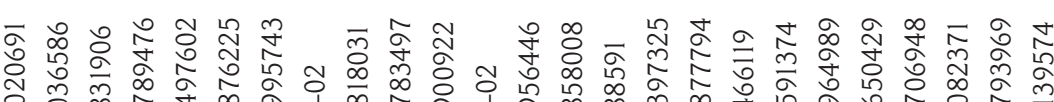
o ల్లై

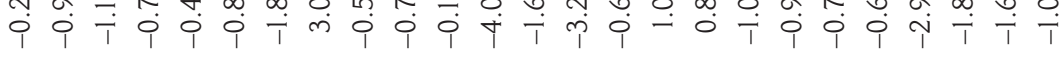

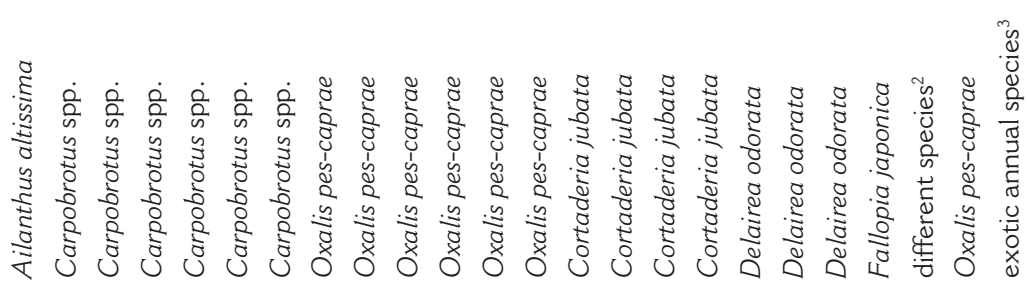
$\frac{0}{0}$

ম 

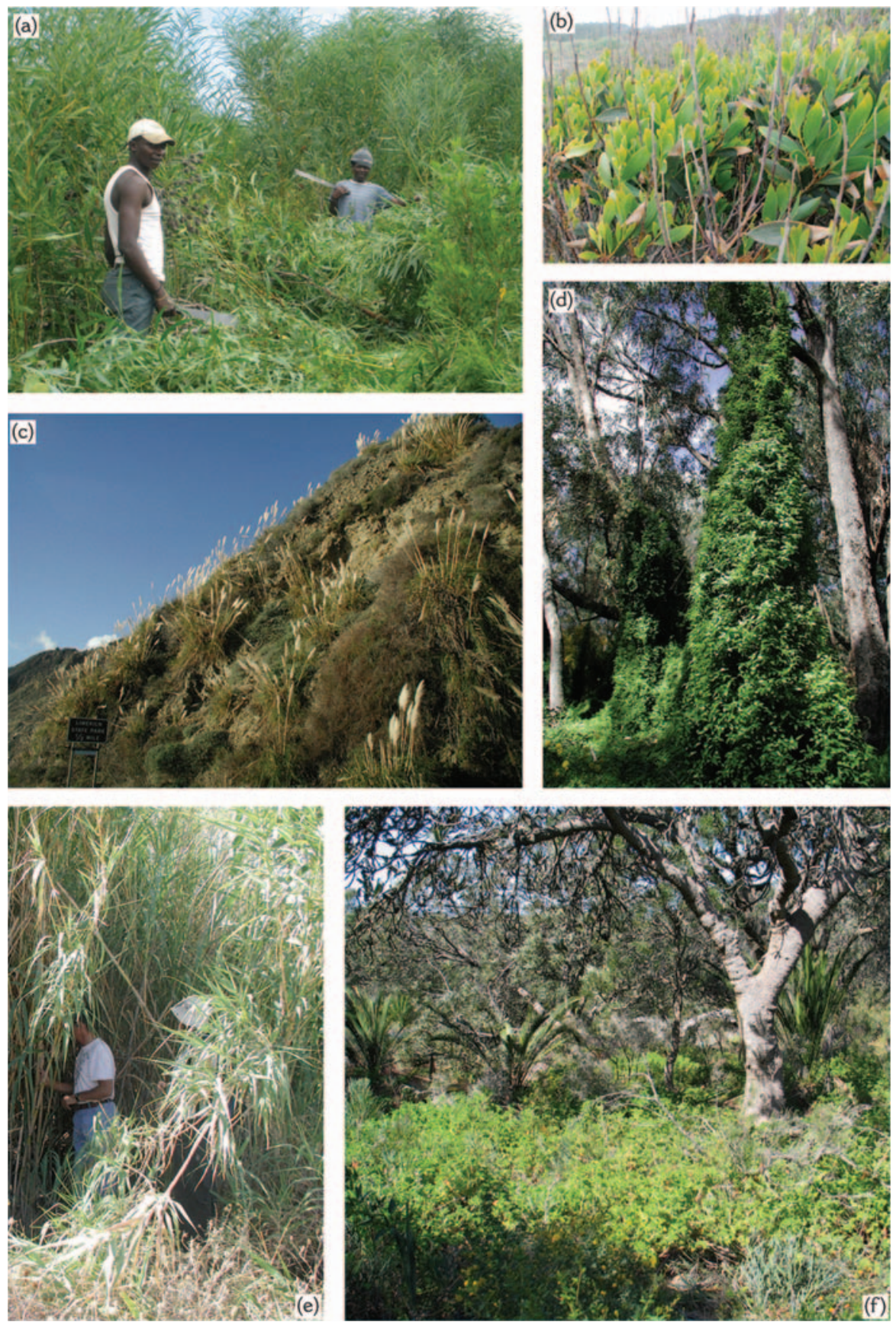

Figure 1 The impacts of invasive alien plants on native plant diversity have been investigated in many Mediterranean-type ecosystems around the world. Examples are: (a) Acacia saligna in South Africa; (b) Acacia longifolia in Portugal; (c) Cortaderia jubata in California, USA; (d) Asparagus asparagoides in Western Australia; (e) Arundo donax in California, USA; (f) Pelargonium capitatum in Western Australia (photo credits: (a) M. Gaertner; (b-f) D.M. Richardson) 
effect size, g (Lipsey and Wilson, 2001; Borenstein et al., 2005), and a mixed (random) effects model was used. A twotail Z-test was used to examine the null hypothesis (ie, the effect size equals zero) and a Q-test was used for the heterogeneity analysis. Meta-analysis can largely alleviate the bias of favouring significant results in literature by weighing each case according to its sampling variance and size, and, as a result, can present a more robust synthesis than traditional literature review.

\section{Results}

The meta-analysis revealed an overall significant decline of species richness after invasion. In five of the 47 cases invasion had a positive effect on native species richness (species richness increased after invasion). In the remaining 42, invaded sites had lower native species richness. Eighteen cases $(38.3 \%)$ had a negative effect size, indicating a significant decline of species richness after invasion, while 29 cases $(61.7 \%)$ had effect sizes not significantly different from zero (ie, 95\% Cl includes 0), indicating no significant decline of species richness after invasion (Figure 2; Table 2). According to Cohen's (1988) standard, 48.9\% of the cases had large effect sizes $(>0.8)$, $36.2 \%$ had medium effect sizes (0.2 0.8), and $14.9 \%$ had small effect sizes.

Effect size of invasion on native species richness declined significantly with increasing unit size. Cases with unit size $<1 \mathrm{~m}^{2}, 1-10 \mathrm{~m}^{2}$ and $10-100 \mathrm{~m}^{2}$ had effect sizes significantly different from zero $(Z=-4.78 ; p<0.001$; $Z=-5.97 ; p<0.001 ; Z=-3.33 ; p<0.001$, respectively). Cases with unit sizes $>100 \mathrm{~m}^{2}$ had effect sizes not significantly different from zero $(Z=-0.45 ; p=0.65)$ (Figure $3 a)$. The same pattern was evident for increasing extent of study area. Effect size was highest for case studies where the extent of the study area was less than $0.01 \mathrm{~km}^{2}$, and decreased with increasing extent of study area, except for studies with areal extent of 100-10 000 $\mathrm{km}^{2}$. Cases with study area extent $<0.01 \mathrm{~km}^{2}$, $1-100 \mathrm{~km}^{2}$ and $100-10000 \mathrm{~km}^{2}$ had effect sizes significantly different from zero $(Z=-4.61$; $p<0.001 ; Z=-2.46 ; p=0.014 ; Z=-5$; $p<0.001$, respectively), whereas cases with extent of study area $0.01-1 \mathrm{~km}^{2}$ and $>10000$ $\mathrm{km}^{2}$ had effect sizes not significantly different from zero $(Z=-1.43 ; p=0.153 ; Z=-0.81$; $p=0.419$, respectively) (Figure $3 b$ ). The time of investigation (temporal scale) also had a significant influence on effect size. Longterm investigations showed a significant higher effect size, with plant invasions having a stronger impact on native species richness than short-term investigations $(Q=13.51$; $\mathrm{p}<0.001)$.

Shrublands, old fields and dune vegetation showed significantly different effect sizes between groups $(\mathrm{Q}=24.31$; $\mathrm{p}<0.001)$ with shrublands and old fields having largest declines in species richness attributable to alien invasion. Invaded sites in forest habitats, in contrast, showed no significant declines in species richness $(Z=-1.33 ; \mathrm{p}=0.18)$. Among the different growth forms of alien plants reviewed, annual herbs, trees and creepers had the greatest impact on species richness decline $(Z=-3.33 ; p<0.001$; $Z=-3.78 ; p<0.001 ; Z=-3.97 ; p<0.001$, respectively), whereas graminoids generally caused insignificant damage to the native communities $(Z=-0.45 ; p=0.65)$ (Figure $4 a)$. An investigation of the different taxa included in the meta-analysis showed the highest effect size of invasion on species richness for two Australian Acacia species (A. melanoxylon and A. saligna) (Figure 4b; Table 2). Among the different countries investigated in the meta-analysis, South Africa had the highest declines of native plant species richness due to alien invasion followed by Australia (Figure 5a). Species with origin in Australia and Europe caused the largest declines in plant species richness (Figure 5b). 


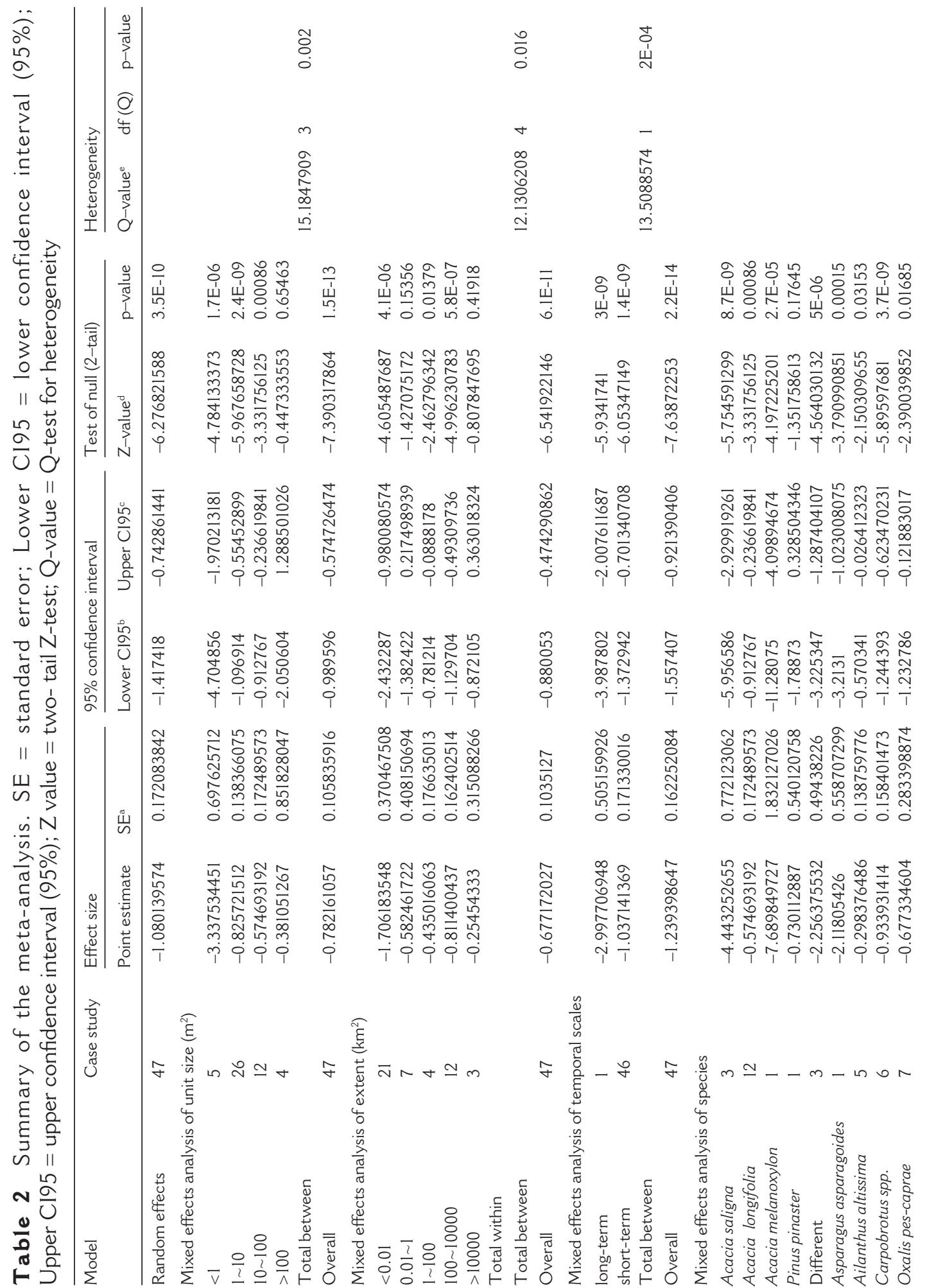


$\frac{}{\stackrel{4}{\sim}}$

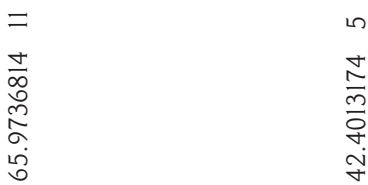

品

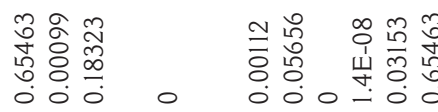

놈

तु

ํㅗㅇ

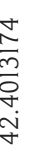

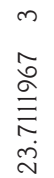

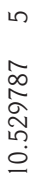

+
$i$
$\infty$
$\infty$
$\infty$
$\stackrel{2}{m}$
$\stackrel{\sim}{\sim}$

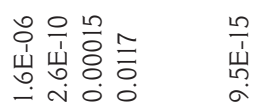

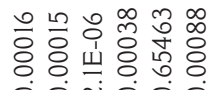

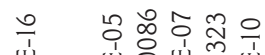

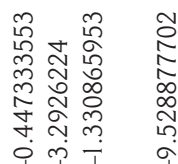

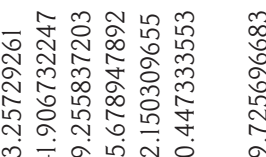

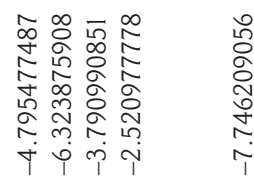

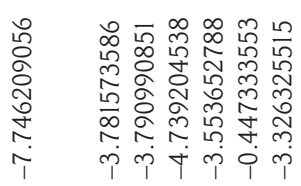

$\stackrel{2}{\equiv}$
$\bar{\sigma}$
$\infty$
0
0
0
$\infty$
$\infty$

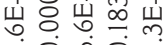

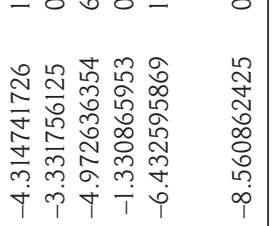

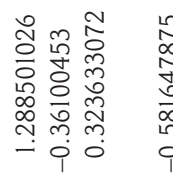

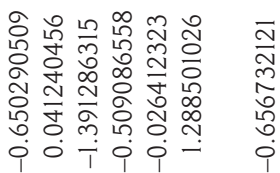

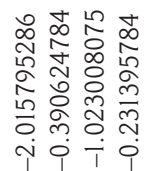

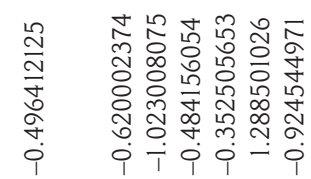

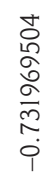

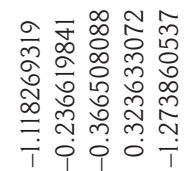

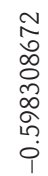

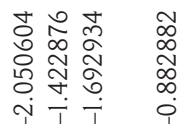

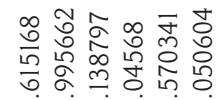

iิ

Nิ
$\infty$
$\infty$
0
0
0

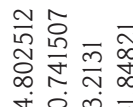

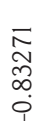

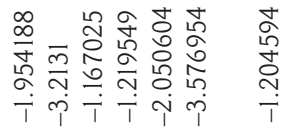

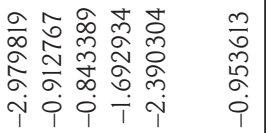

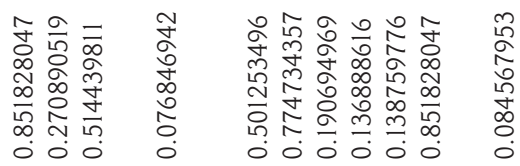

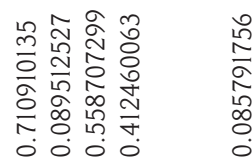

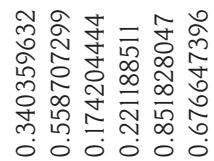

$\overline{0}$
0
0
$\stackrel{0}{0}$
N
0

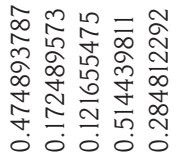

के
ơ
ò
o.
0

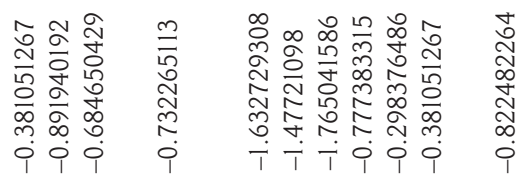

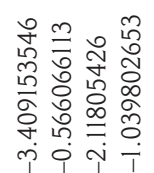

N
0
0
0
$\stackrel{0}{0}$
Oे
0

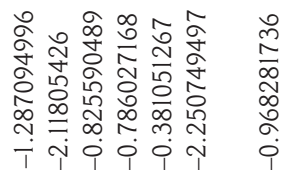

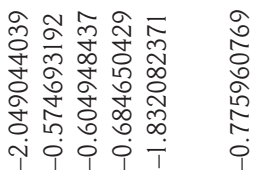

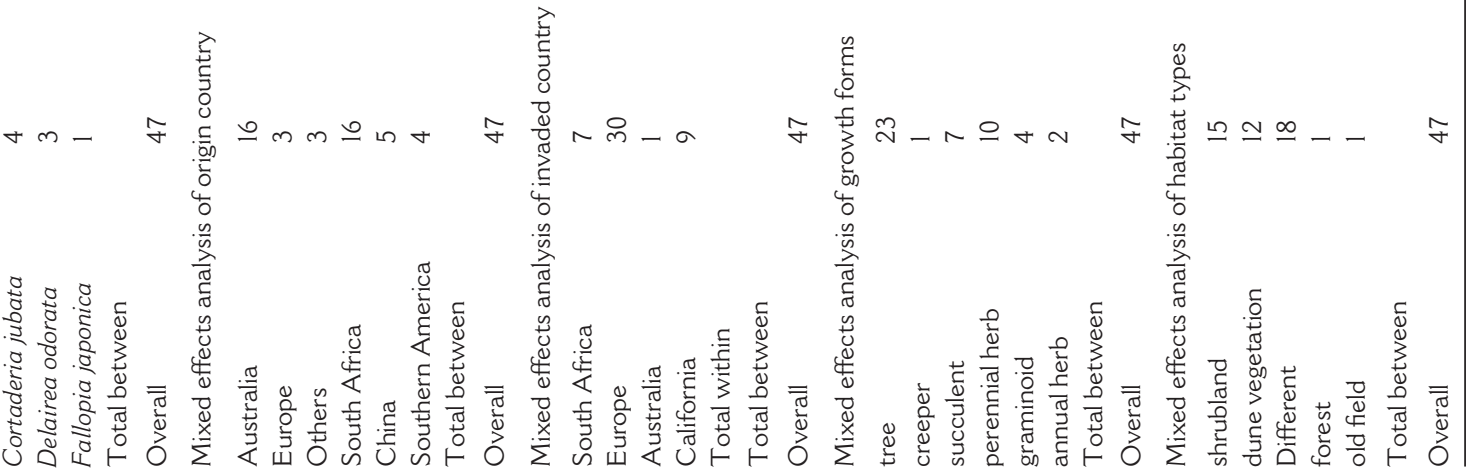




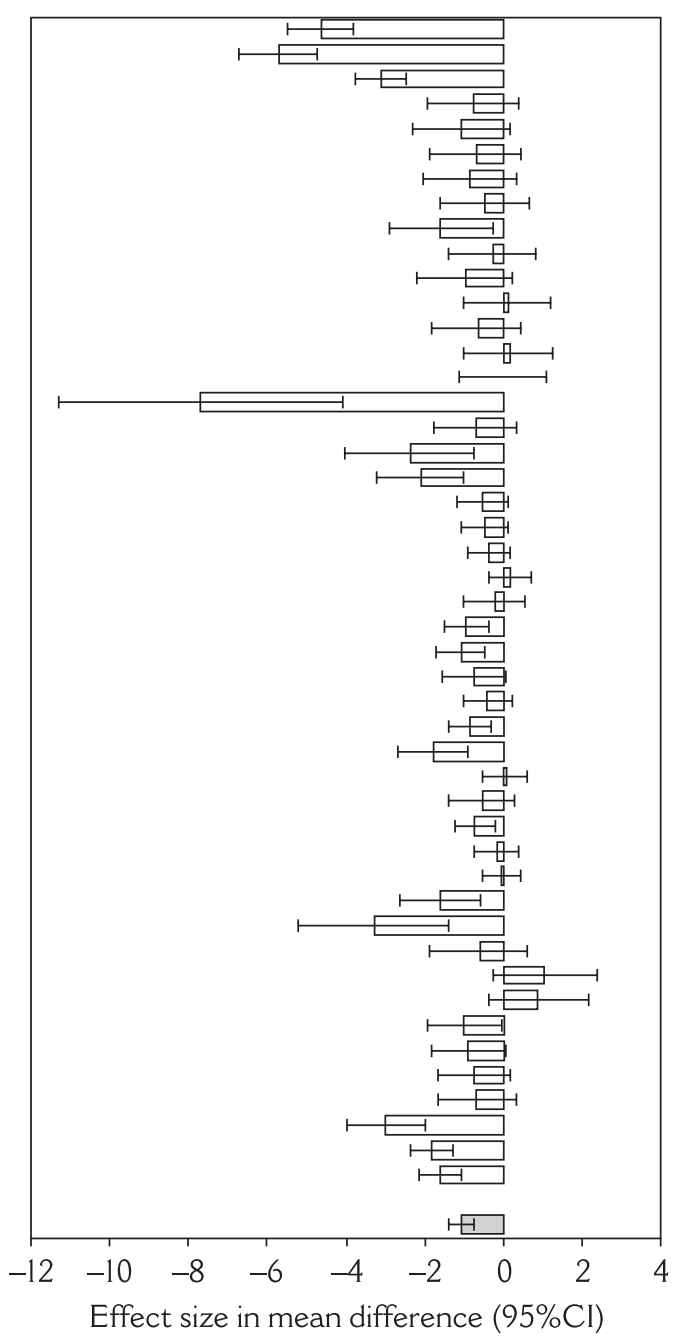

Figure 2 Meta-analysis of species richness of sites invaded by alien species and their natural reference community in four different Mediterranean-type ecosystems. Mean difference effect size, $\mathrm{g}$, and a mixed (random) effects model (indicated in grey) were used. Case studies 1-47 are arranged from top to bottom (see Table 1)

\section{Discussion}

The impact of biological invasions on native ecosystems is the subject of ongoing debate in the literature. Many authors associate invasions with biodiversity declines (Pyšek and
Pyšek, 1995; Higgins et al., 1999; Seabloom et al., 2003; French et al., 2008; Hejda et al., 2009). However, some authors argue that the number of naturalized species far exceeds the number of extinctions and that, on balance, introductions over the past few centuries has increased regional biodiversity levels (Rosenzweig, 2001; Davis, 2003; Brown and Sax, 2004; Gurevitch and Padilla, 2004; Houlahan and Findlay, 2004).

The studies reviewed in this paper show that plant invasions are often associated with a significant decline of native plant species richness. This decline varies according to different spatial and temporal scales. The impact of invasive alien species on native species richness is stronger at small spatial scales and decreases with increasing extent of study area and unit size, respectively. The reason for this is that studies at small scales are more likely to detect effects of competition (Huston, 1999) whereas studies conducted over larger areas are more likely to detect the effects of extrinsic factors (mean sitewide biotic or abiotic factors that covary with biodiversity) (Levine and D'Antonio, 1999). Some theories predict that at larger scales increased heterogeneity in resource availability and site conditions may favour the coexistence of native and invasive alien species, provided that they have different functional traits, competitive ability and resource optima (Davies et al., 2005; Smith and Shurin, 2006; Melbourne et al., 2007). Taking this theory further, one could argue that high heterogeneity at large spatial scales promotes diversity of both native and alien species. However, patterns of species diversity at larger scales (ie, regional or subglobal scales) do not necessarily reflect the impact on local biotic interactions (Smith and Shurin, 2006). Our meta-analysis clearly shows that invasions can reduce species richness at small scales.

Another important factor is temporal scale. Investigations in areas with a long invasion history revealed a much stronger impact of invasive alien species on native species 

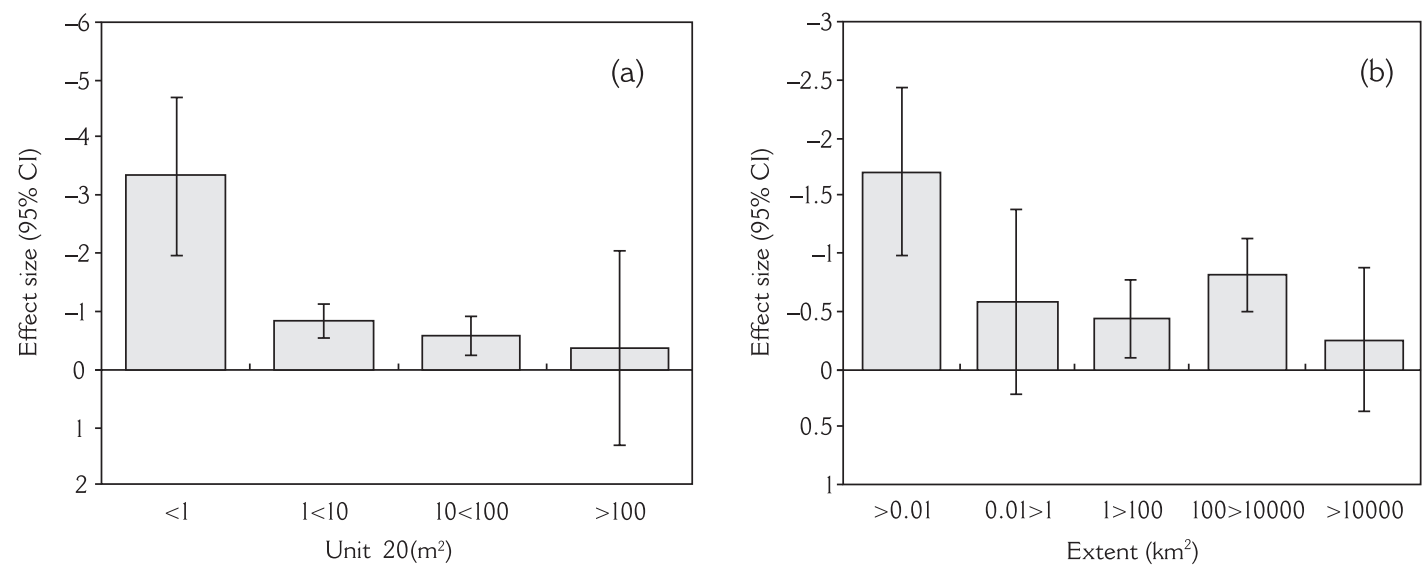

Figure 3 Effect size $(95 \% \mathrm{Cl})$ of invasion on species richness for different (a) unit sizes $\left(\mathrm{m}^{2}\right)$ and (b) extents $\left(\mathrm{km}^{2}\right)$ in Mediterranean-type ecosystems. Q-test shows significant different effect sizes (heterogeneity) between groups ( $a: Q=15.18, p<0.01$; $\mathrm{b}: \mathrm{Q}=12.13, \mathrm{p}=0.02$ )
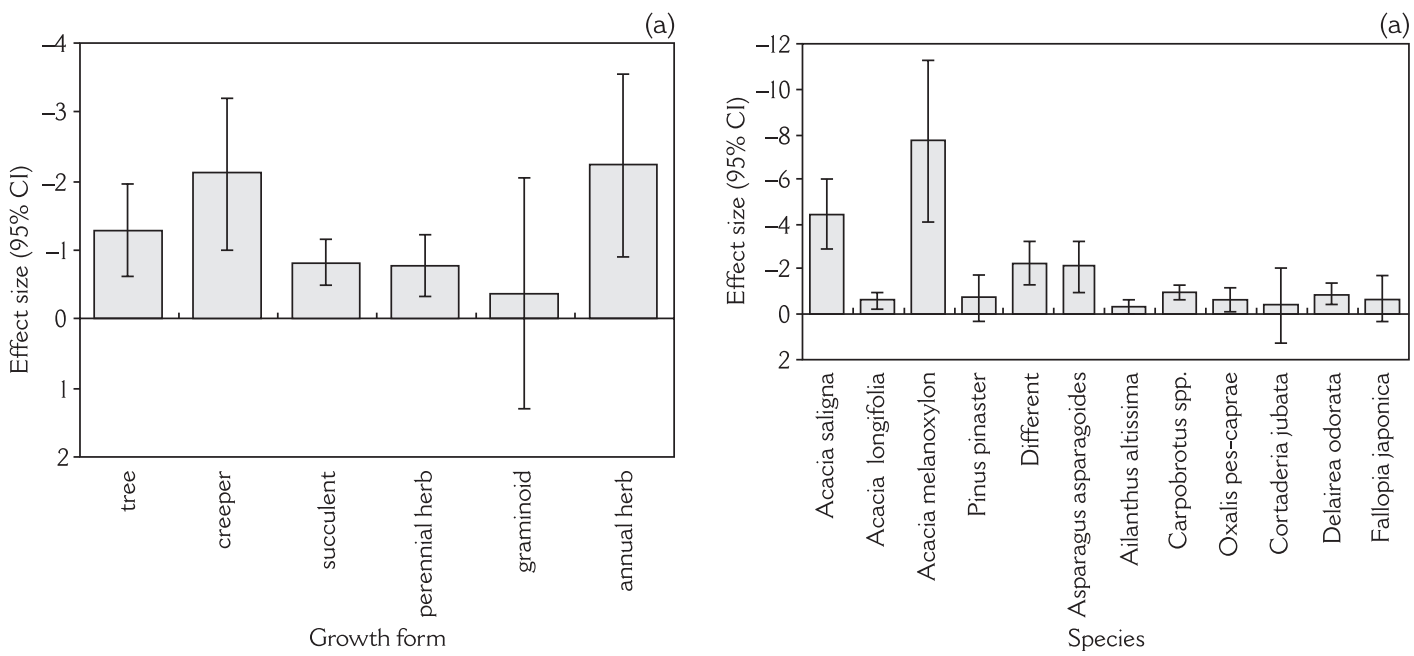

Figure 4 Comparison of the effect size $(95 \% \mathrm{Cl})$ on species richness from species with different (a) growth forms and (b) taxonomical groups in Mediterranean-type ecosystems. Q-test shows no significant different among growth forms $(\mathrm{Q}=10.53$; $p=0.062$ ), but significant difference of effect sizes (heterogeneity) between species $(\mathrm{Q}=65.97 ; \mathrm{p}<0.001)$

richness than studies in recently invaded areas. This finding is supported by a long-term study from permanent plots which demonstrates a decline of plant species richness over a 10-year timeframe of Lonicera japonica invasion (Yurkonis and Meiners, 2004).
Richardson et al. (2007) argued that a timelag between invasions and extinctions could be the reason for the temporary increase of species richness after invasions. Timelags in extinctions could create, and have already created, a large extinction debt which could 

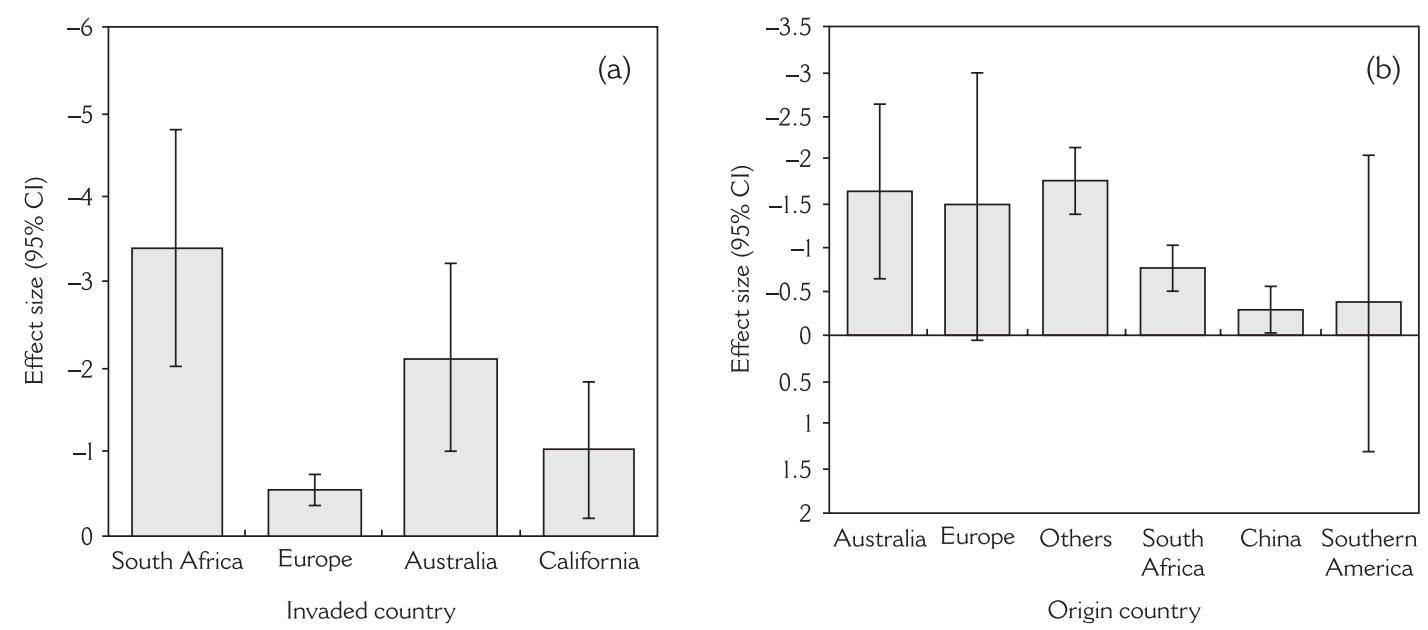

Figure 5 Comparison of the effect size $(95 \% \mathrm{Cl})$ of invasion on species richness in (a) different invaded countries and (b) the effect size of invasion from species with different countries of origin in Mediterranean-type ecosystems. Q-test shows significant different effect sizes (heterogeneity) between groups ( $a$ : $Q=23.7, p<0.001$; b: $\mathrm{Q}=42.4, \mathrm{p}<0.001)$

be paid in future even with no further introduction of alien plant species (Tilman et al., 1994; Sax and Gaines, 2008). Processes of extinction debt have also been recorded for extinctions related to habitat destruction or fragmentation (Helm et al., 2006). Another interesting aspect is that invasive alien species might not have a direct impact on extinction rates through competitive displacement of established plant species but rather influence colonization rates, thus leading to declines of local diversity (Yurkonis and Meiners, 2004).

Levine et al. (2003), in their review of mechanisms underlying the impact of alien plant invasions, posit that it is very difficult to uncover simple rules concerning which invaders or functional groups are most likely to exert large impacts across systems, or which communities will be most susceptible to impacts. Hejda et al. (2009) found that a decrease in species richness after alien invasion was largely driven by the identity of the invading species. We could detect patterns relating to the most successful growth forms among invaders and relating to the types of native habitats most affected by invaders. Shrublands were significantly affected by alien invasion. Trees are the growth form with the highest impact on native species richness, whereas graminoids caused insignificant reductions. These results are consistent with findings from Mason et al. (2009), who found a strong negative effect of woody invaders but little effect of graminoids on shrub species richness. Shrublands in MTEs generally lack tree species and therefore a decline of species richness might be caused by canopy-level changes due to tree invasions. Tree invasion results in higher canopy cover (Rejmánek, 1989), which might lead to species declines through shading effects. Investigations in the South African fynbos and Australian kwongan suggest that even high densities of indigenous overstorey shrubs (Proteaceae species) lead to a decrease in species richness of native plant species (Specht and Specht, 1989; Cowling and Gxaba, 1990; Vlok and Yeaton, 2000). The comparatively low impact of graminoids on native species richness in our meta-analysis was unexpected. Invasive alien grasses are seen as a serious challenge, 
especially in North America (Seabloom et al., 2003; Callaway and Ridenour, 2004; Moyes et al., 2005; Seastedt and Suding, 2007) but also in other parts of the world (Clarke et al., 2005; Musil et al., 2005). The decline of plant species richness is obviously only one measure of the impact of invasions on invaded ecosystems. The indirect effect of invasive grasses on floristic composition by changing fire regimes is widely recognized as a significant ecological factor (Brooks et al., 2004; Clarke et al., 2005; Rossiter-Rachor et al., 2008).

Old fields showed significant declines in species richness after invasion. Anthropogenically disturbed habitats have been described as habitats with highest frequency and number of alien species (Vilà et al., 2007). Invasions in old fields often hamper successional dynamics and old fields remain in a degraded state once invaded as alien species establish persistent communities that prevent the establishment of native species (Cramer et al., 2008).

Forest habitats were less affected by alien invasions than other habitat types. In general, undisturbed and successionally advanced communities are less invasible than other habitats (Rejmánek, 1989). This finding is supported by studies in Poland (Knight et al., 2008) and Australia (Mason et al., 2009). Introduced Australian Acacia species caused the most severe decline of native species richness, with South Africa being the most affected country. Invasions of Australian Acacia species in fynbos are of particular concern. Australian Acacia species have a huge invasive potential and strong persistence due to enormous loads of long-lived seeds (Richardson and Kluge, 2008). They therefore have radically increased biomass and changed fuel properties in fynbos ecosystems (van Wilgen and Richardson, 1985). Apart from this, Acacia species have massive influences due to nitrogen fixation (Yelenik et al., 2004). These factors in combination have wreaked havoc on fynbos communities.

One could conclude that species introduced from regions with similar climates within MTEs have much stronger impacts, with the native species richness in South Africa declining most severely due to invasion by Australian Acacia species. However, this conclusion might be premature as this cohesion could simply be caused by the fact that Australian Acacia species were not distributed equally to all the investigated countries.

When investigating declines of native species richness due to alien invasions one has to consider that in many instances invasive alien species have been found to be symptomatic of land-use change (Maskell et al., 2006). In other words, many invaded systems are heavily impacted by habitat loss and disturbance (MacDougall and Turkington, 2005). This led to the reasoning that invasive species might be 'passengers' of degraded ecosystems rather than acting as drivers of degradation. One theory of invader success is that alien species fill unoccupied niches after extinction of native species due to degradation (Shea and Chesson, 2002). Because there might be pre-existing differences prior to invasion, it is difficult to attribute extinctions exclusively to the influence of alien plants.

Indeed most threatened species face more than one threat. It is difficult to disentangle the proximate and ultimate causes of decline or interactions between threats and to evaluate their relative importance (Gurevitch and Padilla, 2004). For example, habitat loss has been identified as the primary cause of extinctions at local and meta community levels in most areas of the world (Davis, 2003). Furthermore, an assessment of threats on biodiversity in the Mediterranean biome showed that both threatened mammals and plants had a negative correlative relationship with the amount of available natural area, with more species threatened when less area remained (Underwood et al., 2009). The question of which factor is most responsible for species declines and which of the factors are drivers or passengers is secondary as ultimately global biodiversity is changing at an 
unprecedented rate (Sala et al., 2000) and it is crucial to minimize any impacts.

To understand impacts of alien invasions on native ecosystems it is important to investigate underlying mechanisms. Studies on impacts of invasive species on ecosystem processes concentrate mainly on one mechanism at a time. There are studies which investigate changes of above-ground vegetation due to alien plant invasion (Holmes, 1990; D' Antonio and Mahall, 1991; Blanchard and Holmes, 2008). Other studies concentrate on changes in the soil seed bank (Wearne and Morgan, 2006; Fourie, 2008; Vosse et al., 2008), or changes of soil chemical properties (Witkowski, 1991; Musil, 1993; Yelenik et al., 2004; Lindsay and French, 2005). A range of papers look at competitive interactions between native and invasive plant species (D'Antonio and Mahall, 1991; Sans et al., 2004; Garcia-Serrano et al., 2007; French et al., 2008), while others focus on allelopathic mechanisms (Ridenour and Callaway, 2001; Bais et al., 2003) or a change in soil microorganisms (Allsopp and Holmes, 2001). Assumptions about correlations between changes of vegetation structure and composition and the above-mentioned factors have been made (Holmes, 1990; Musil, 1993). However, our understanding about the interactions between the different mechanisms remains rudimentary. Further research should concentrate on mechanisms underlying alien plant invasions to get a better understanding about which factors are ultimately responsible for a decrease of native species richness.

The meta-analysis approach, although most useful for uncovering the patterns described above, clearly has some limitations that must be considered when evaluating the patterns that have emerged in this study. One problem relates to a potential publication bias in favour of studies that show strong negative impacts on biodiversity: we suggest that studies demonstrating significant impacts are more likely to be published overall than those reporting insignificant impacts. We feel that we have reduced the effect of this potential bias to some extent by including studies from a wide range of journals (ranging from top-tier publications to those with low impact factors), rather than limiting the review to papers in a specific set of journals (high-impact journals are more likely to report dramatic effects, whereas studies with non-significant effects are more likely to be published in journals with lower impact factors). Furthermore, meta-analysis, to a large degree, eliminates bias caused by significant studies with low sample sizes and high sample variance. Nonetheless, some invasive plant species have little or no de-tectable impact (examples of such 'benign invaders' are listed in Richardson et al. (2000: 101), which contribute much weight to the metaanalysis, especially when species richness shows little variation over a large number of samples. Given that, we feel that metaanalysis can improve the robustness of syntheses and should be used in further studies on the mechanisms causing biodiversity decline and biotic homogenization.

Another limitation which has to be considered is the fact that the studies which were included in the meta-analysis all use space for time substitution. The comparison of invaded and uninvaded sites introduces some uncertainty regarding the character of the invaded site prior to invasion.

\section{Conclusions}

We have confirmed that in most cases where the effects of plant invasions on native plant diversity have been assessed in Mediterranean-type ecosystems, there are clear negative impacts. It has often been acknowledged that the type and magnitude of impacts depend on the spatial and temporal scale (Sax et al., 2002; Davies et al., 2005). However, our study highlights the importance of the growth form of the invading species, the invaded habitat, as well as the area of investigation. Our study confirmed that invasions indeed cause a marked decline of native plant species richness. Since most 
of the invasions that were included in our meta-analysis are fairly recent (mostly a few decades) and the results show that the magnitude of impacts increases markedly over time, there is no doubt that declines in species richness is likely to escalate rapidly. These results provide further motivation for urgent action to reduce the extent of alien plant invasions in Mediterranean-type ecosystems.

\section{Acknowledgements}

We thank the DST-NRF Centre ofExcellence for Invasion Biology for financial support and Petr Pyšek and Marcel Rejmanek for helpful comments.

\section{References}

Allsopp, N. and Holmes, P.M. 2001: The impact of alien plant invasion on mycorrhizas in mountain fynbos vegetation. South African Journal of Botany 67, 150-56.

Alvarez, M.E. and Cushman, J.H. 2002: Communitylevel consequences of a plant invasion: effects on three habitats in coastal California. Ecological Applications 12, 1434-44.

Aschmann, H. 1973: Distribution and peculiarity of Mediterranean ecosystems. In Di Castri, F. and Mooney, H.A., editors, Mediterranean type ecosystems, London: Chapman and Hall, 391.

Ashton, I.W., Hyatt, L.A., Howe, K.M., Gurevitch, J. and Lerdau, M. T. 2005: Invasive species accelerate decomposition and litter nitrogen loss in a mixed deciduous forest. Ecological Applications 15, 1263-72.

Bais, H.P., Vepachedu, R., Gilroy, S., Callaway, R.M. and Vivanco, J.M. 2003: Allelopathy and exotic plant invasion: from molecules and genes to species interactions. Science 301, 1377-80.

Blanchard, R. and Holmes, P.M. 2008: Riparian vegetation recovery after invasive alien tree clearance in the fynbos biome. South African Journal of Botany 74, 421-31.

Borenstein, M., Hedges, L., Higgins, J. and Rothstein, H. 2005: Comprehensive meta-analysis, version 2. Englewood, NJ: Biostat.

Brooks, M.L., D'Antonio, C.M., Richardson, D.M., Grace, J.B., Keeley, J.E., Di Tomaso, J.M., Hobbs, R.J., Pellant, M. and Pyke, D. 2004: Effects of invasive alien plants on fire regimes. BioScience 54, 677-88.

Brown, J.H. and Sax, D.F. 2004: An essay on some topics concerning invasive species. Austral Ecology 29, 530-36.
Callaway, R.M. and Ridenour, W.M. 2004: Novel weapons: invasive success and the evolution of increased competitive ability. Frontiers in Ecology and the Environment 2, 436-43.

Clarke, P.J., Latz, P.K. and Albrecht, D.E. 2005: Long-term changes in semi-arid vegetation: invasion of an exotic perennial grass has larger effects than rainfall variability. Journal of Vegetation Science 16, 237-48.

Cohen, J. 1988: Statistical power analysis for the behavioral sciences. New York: Academic Press.

Cowling, R.M. and Gxaba, T. 1990: Effects of a fynbos overstorey shrub on understorey community structure: implications for the maintenance of community wide species richness. South African Journal of Ecology 1, 1-7.

Cowling, R.M., Rundel, P.W., Lamont, B.B., Arroyo, M.K. and Arianoutsou, M. 1996: Plant diversity in Mediterranean-climate regions. Trends in Ecology and Evolution 11, 362-66.

Cramer, V.A., Hobbs, R.J. and Standish, R.J. 2008: What's new about old fields? Land abandonment and ecosystem assembly. Trends in Ecology and Evolution 23, 104-12.

Dallman, P.R. 1998: Plant life in the world's mediterranean climates. Oxford: Oxford University Press.

D'Antonio, C.M. and Mahall, B.E. 1991: Root profiles and competition between the invasive, exotic perennial, Carpobrotus edulis, and two native shrub species in California coastal scrub. American Journal of Botany 78, 885-94.

Davies, K.F., Chesson, P., Harrison, S., Inouye, B.D., Melbourne, B.A. and Rice, K.J. 2005: Spatial heterogeneity explains the scale dependence of the native-exotic diversity relationship. Ecology 86, 1602-10.

Davis, M.A. 2003: Biotic globalization: does competition from introduced species threaten biodiversity? Bioscience 53, 481-89.

- 2009: Invasion biology. Oxford: Oxford University Press.

Fourie, S. 2008: Composition of the soil seed bank in alien-invaded grassy fynbos: potential for recovery after clearing. South African Journal of Botany 74, 445-53.

French, K., Ens, E., Gosper, C.R., Lindsay, E., Mason, T., Owers, B. and Sullivan, N. 2008: Management implications of recent research into the effect of bitou bush invasion. Plant Protection Quarterly 23, 24-28.

Fridley, J.D., Stachowicz, J.J., Naeem, S., Sax, D.F., Seabloom, E.W., Smith, M.D., Stohlgren, T.J., Tilman, D. and von Holle, B. 2007: The invasion paradox: reconciling pattern and process in species invasions. Ecology 88, 3-17.

Garcia-Serrano, H., Sans, F.X. and Escarre, J. 2007: Interspecific competition between alien and 
native congeneric species. Acta Oecologica 31, 69-78.

Groves, R.H. and Di Castri, F. 1991: Biogeography of Mediterranean invasions. Cambridge: Cambridge University Press.

Gurevitch, J. and Padilla, D.K. 2004: Are invasive species a major cause of extinctions? Trends in Ecology and Evolution 19, 470-74.

Hejda, M. and Pyšek, P. 2006: What is the impact of Impatiens glandulifera on species diversity of invaded riparian vegetation? Biological Conservation 132, 143-52.

Hejda, M., Pyšek, P. and Jarošík, V. 2009: Impact of invasive plants on the species richness, diversity and composition of invaded communities. Journal of Ecology 97, 393-403.

Helm, A., Hanski, I. and Partel, M. 2006: Slow response of plant species richness to habitat loss and fragmentation. Ecology Letters 9, 72-77.

Higgins, S.I., Richardson, D.M., Cowling, R.M. and Trinder-Smith, T.H. 1999: Predicting the landscape-scale distribution of alien plants and their threat to plant diversity. Conservation Biology 13, 303-13.

Holmes, P.M. 1990: Dispersal and predation in alien Acacia. Oecologia 83, 288-90.

Holmes, P.M. and Cowling, R.M. 1997: The effects of invasion by Acacia saligna on the guild structure and regeneration capabilities of South African fynbos shrublands. Journal of Applied Ecology 34, 317-32.

Houlahan, J.E. and Findlay, C.S. 2004: Effect of invasive plant species on temperate wetland plant diversity. Conservation Biology 18, 1132-38.

Huston, M.A. 1999: Local processes and regional patterns: appropriate scales for understanding variation in the diversity of plants and animals. Oikos 86, 393-401.

Knight, K.S., Oleksyn, J., Jagodzinski, A.M., Reich, P. B. and Kasprowicz, M. 2008: Overstorey tree species regulate colonization by native and exotic plants: a source of positive relationships between understorey diversity and invasibility. Diversity and Distributions 14, 666-75.

Köppen, W. 1923: Die Klimate der Erde. Berlin: Bornträger.

Kruger, F.J., Breytenbach, G.J., Macdonald, I.A.W. and Richardson, D.M. 1989: Characteristics of invaded Mediterranean-type regions. In Drake, J., Di Castri, F., Groves, R., Kruger, F.J., Mooney, H.A., Rejmánek, M. and Williamson, M., editors, Biological invasions: a global synthesis, Chichester: Wiley, 181-213.

Lambrinos, J.G. 2000: The impact of the invasive alien grass Cortaderia jubata (Lemoine) Stapf on an endangered Mediterranean-type shrubland in California. Diversity and Distributions 6, 217-31.
Levine, J.M. and D'Antonio, C.M. 1999: Elton revisited: a review of evidence linking diversity and invasibility. Oikos 87, 15-26.

Levine, J.M., Vila, M., D'Antonio, C.M., Dukes, J.S., Grigulis, K. and Lavorel, S. 2003: Mechanisms underlying the impacts of exotic plant invasions. Proceedings of the Royal Society of London Series B-Biological Sciences 270, 775-81.

Lindsay, E.A. and French, K. 2005: Litterfall and nitrogen cycling following invasion by Chrysanthemoides monilifera ssp rotundata in coastal Australia. Journal of Applied Ecology 42, 556-66.

Lipsey, M.W. and Wilson, D.B. 2001: Practical metaanalysis. London: Sage.

MacDougall, A.S. and Turkington, R. 2005: Are invasive species the drivers or passengers of change in degraded ecosystems? Ecology 86, 42-55.

Marchante, H., Marchante, E. and Freitas, H. 2003: Invasion of the Portuguese dune ecosystems by the exotic species Acacia longifolia (Andrews) Willd.: effects at the community level. Plant invasions: ecological threats and management solutions. Leiden: Backhuys, 75-85.

Maskell, L.C., Bullock, J.M., Smart, S.M., Thompson, K. and Hulme, P.E. 2006: The distribution and habitat associations of non-native plant species in urban riparian habitats. Journal of Vegetation Science 17, 499-508.

Mason, T.J., French, K. and Lonsdale, W.M. 2009: Do graminoid and woody invaders have different effects on native plant functional groups? Journal of Applied Ecology 46, 426-33.

Melbourne, B.A., Cornell, H.V., Davies, K.F., Dugaw, C.J., Elmendorf, S., Freestone, A.L., Hall, R.J., Harrison, S., Hastings, A., Holland, M., Holyoak, M., Lambrinos, J., Moore, K. and Yokomizo, H. 2007: Invasion in a heterogeneous world: resistance, coexistence or hostile takeover? Ecology Letters 10, 77-94.

Moyes, A.B., Witter, M.S. and Gamon, J.A. 2005 : Restoration of native perennials in a California annual grassland after prescribed spring burning and solarization. Restoration Ecology 13, 659-66.

Musil, C.F. 1993: Effect of invasive Australian Acacias on the regeneration, growth and nutrient chemistry of South-African lowland fynbos. Journal of Applied Ecology 30, 361-72.

Musil, C.F., Milton, S.J. and Davis, G.W. 2005: The threat of alien invasive grasses to lowland Cape floral diversity: an empirical appraisal of the effectiveness of practical control strategies. South African Journal of Science 101, 337-44.

Pauchard, A., Cavieres, L.A. and Bustamante, R.O. 2004: Comparing alien plant invasions among regions with similar climates: where to from here? Diversity and Distributions 10, 371-75. 
Petsikos, C., Dalias, P. and Troumbis, A.Y. 2007: Effects of Oxalis pes-caprae L. invasion in olive groves. Agriculture Ecosystems and Environment 120, 325-29.

Pyšek, P. and Pyšek, A. 1995: Invasion by Heracleum mantegazzianum in different habitats in the CzechRepublic. Journal of Vegetation Science 6, 711-18.

Pyšek, P., Richardson, D.M., Rejmánek, M., Webster, G.L., Williamson, M. and Kirschner, J. 2004: Alien plants in checklists and floras: towards better communication between taxonomists and ecologists. Taxon 53, 131-43.

Rejmánek, M. 1989: Invasibility of plant communities. In Drake, J.A., Mooney, H.A., Di Castri, F., Groves, R.H., Kruger, F.J., Rejmánek, M. and Williamson, M., editors, Biological invasion: a global perspective, Chichester: Wiley, 369-88.

Rejmánek, M. and Randall, J.M. 1994: Invasive alien plants in California: 1993 summary and comparison with other areas in North America. Madroño 41, 161-77.

Richardson, D.M. and Kluge, R.L. 2008: Seed banks of invasive Australian Acacia species in South Africa: role in invasiveness and options for management. Perspectives in Plant Ecology, Evolution and Systematics 10, 161-77.

Richardson, D.M., Holmes, P.M., Esler, K.J., Galatowitsch, S.M., Stromberg, J.C., Kirkman, S.P., Pyšek, P. and Hobbs, R.J. 2007: Riparian vegetation: degradation, alien plant invasions, and restoration prospects. Diversity and Distributions 13 , 126-39.

Richardson, D.M., MacDonald, I.A.W. and Forsyth, G.G. 1989: Reductions in plant species richness under stands of alien trees and shrubs in the fynbos Biome. South African Forestry Journal $149,1-8$.

Richardson, D.M., Macdonald, I.A.W., Holmes, P.M. and Cowling, R.M. 1992: Plant and animal invasions. In Cowling, R.M., editor, The ecology of fynbos: nutrients, fire and diversity, Cape Town: Oxford University Press.

Richardson, D.M., Pyšek, P., Rejmánek, M., Barbour, M.G., Panetta, F.D. and West, C.J. 2000: Naturalization and invasion of alien plants: concepts and definitions. Diversity and Distributions 6, 93-107.

Ridenour, W.M. and Callaway, R.M. 2001: The relative importance of allelopathy in interference: the effects of an invasive weed on a native bunchgrass. Oecologia 126, 444-50.

Rosenzweig, M.L. 2001: The four questions: what does the introduction of exotic species do to diversity? Evolutionary Ecology Research 3, 361-67.

Rossiter-Rachor, N.A., Setterfield, S.A., Douglas, M.M., Hutley, L.B. and Cook, G.D. 2008: Andropogon gayanus (Gamba grass) invasion increases fire-mediated nitrogen losses in the tropical savannas of northern Australia. Ecosystems 11, 77-88.

Rouget, M., Richardson, D.M., Cowling, R.M., Lloyd, J.W. and Lombard, A.T. 2003: Current patterns of habitat transformation and future threats to biodiversity in terrestrial ecosystems of the Cape Floristic Region, South Africa. Biological Conservation 112, 63-85.

Sala, O.E., Chapin, F.S., Armesto, J.J., Berlow, E., Bloomfield, J., Dirzo, R., Huber-Sanwald, E., Huenneke, L.F., Jackson, R.B., Kinzig, A., Leemans, R., Lodge, D.M., Mooney, H.A., Oesterheld, M., Poff, N.L., Sykes, M.T., Walker, B.H., Walker, M. and Wall, D.H. 2000: Biodiversity - global biodiversity scenarios for the year 2100. Science 287, 1770-74.

Sans, F.X., Garcia-Serrano, H. and Afan, I. 2004: Life-history traits of alien and native Senecio species in the Mediterranean region. Acta Oecologica -International Journal of Ecology 26, 167-78.

Sax, D.F. 2002: Native and naturalized plant diversity are positively correlated in scrub communities of California and Chile. Diversity and Distributions 8, 193-210.

Sax, D.F. and Gaines, S.D. 2008: Species invasions and extinction: the future of native biodiversity on islands. Proceedings of the National Academy of Sciences of the United States of America 105, 11,490-97.

Sax, D.F., Gaines, S.D. and Brown, J.H. 2002: Species invasions exceed extinctions on islands worldwide: a comparative study of plants and birds. American Naturalist 160, 766-83.

Seabloom, E.W., Harpole, W.S., Reichman, O.J. and Tilman, D. 2003: Invasion, competitive dominance, and resource use by exotic and native California grassland species. Proceedings of the National Academy of Sciences of the United States of America 100, 13,384-89.

Seabloom, E.W., Williams, J.W., Slayback, D., Stoms, D.M., Viers, J.H. and Dobson, A.P. 2006: Human impacts, plant invasion, and imperiled, plant species in California. Ecological Applications 16, 1338-50.

Seastedt, T.R. and Suding, K.N. 2007: Biotic constraints on the invasion of diffuse knapweed (Centaurea diffusa) in North American grasslands. Oecologia 151, 626-36.

Shea, K. and Chesson, P. 2002: Community ecology theory as a framework for biological invasions. Trends in Ecology and Evolution 17, 170-76.

Smith, M.L. and Glass, G.V. 1977: Meta-analysis of psychotherapy outcome studies. American Psychologist 32, 752-60.

Smith, S.A. and Shurin, J.B. 2006: Room for one more? Evidence of invasibility and saturation in ecological communities. In Cadotte, M.W., 
MacMahon, S.M. and Fukami, T., editors, Conceptual ecology and invasion biology: reciprocal, Dordrecht: Springer, 423-47.

Specht, R.L. and Specht, A. 1989: Species richness of sclerophyll (heathy) plant-communities in Australia - the influence of overstory cover. Australian Journal of Botany 37, 337-50.

Stylinski, C.D. and Allen, E.B. 1999: Lack of native species recovery following severe exotic disturbance in southern Californian shrublands. Journal of Applied Ecology 36, 544-54.

Tilman, D., May, R.M., Lehman, C.L. and Nowak, M.A. 1994: Habitat destruction and the extinction debt. Nature 371, 65-66.

Traveset, A. and Richardson, D.M. 2006: Biological invasions as disruptors of plant reproductive mutualisms. Trends in Ecology and Evolution 21, 208-16.

Turner, P.J., Scott, J.K. and Spafford, H. 2008: The ecological barriers to the recovery of bridal creeper (Asparagus asparagoides (L.) Druce) infested sites: impacts on vegetation and the potential increase in other exotic species. Austral Ecology 33, 713-22.

Underwood, E.C., Viers, J.H., Klausmeyer, K.R., Cox, R.L. and Shaw, M.R. 2009: Threats and biodiversity in the Mediterranean biome. Diversity and Distributions 15, 188-97.

Vanderhoeven, S., Dassonville, N. and Meerts, P. 2005: Increased topsoil mineral nutrient concentrations under exotic invasive plants in Belgium. Plant and Soil 275, 169-79.

van Wilgen, B.W. and Richardson, D.M. 1985: The effects of alien shrub invasions on vegetation structure and fire behaviour in South African fynbos shrublands: a simulation study. Journal of Applied Ecology 22, 955-66.

Vilà, M., Pino, J. and Font, X. 2007: Regional assessment of plant invasions across different habitat types. Journal of Vegetation Science 18, 35-42.
Vilà, M., Tessier, M., Suehs, C.M., Brundu, G., Carta, L., Galanidis, A., Lambdon, P., Manca, M., Médail, F., Moragues, E., Traveset, A., Troumbis, A.Y. and Hulme, P.E. 2006: Local and regional assessments of the impacts of plant invaders on vegetation structure and soil properties of Mediterranean islands. Journal of Biogeography 33, 853-61.

Vlok, J.H.J. 1988: Alpha-diversity of lowland fynbos herbs at various levels of infestation by alien annuals. South African Journal of Botany 54, 623-27.

Vlok, J.H.J. and Yeaton, R.I. 2000: Competitive interactions between overstorey proteas and sprouting understorey species in South African mountain fynbos. Diversity and Distributions 6 , 273-81.

Vosse, S., Esler, K.J., Richardson, D.M. and Holmes, P.M. 2008: Can riparian seed banks initiate restoration after alien plant invasion? Evidence from the Western Cape, South Africa. South African Journal of Botany 74, 432-44.

Wearne, L.J. and Morgan, J.W. 2006: Shrub invasion into subalpine vegetation: implications for restoration of the native ecosystem. Plant Ecology 183, 361-76.

Wilcove, D.S., Rothstein, D., Jason, D., Phillips, A. and Losos, E. 1998: Quantifying threats to imperiled species in the United States. BioScience 48, 607-15.

Witkowski, E.T.F. 1991: Effects of invasive alien Acacias on nutrient cycling in the coastal lowlands of the Cape Fynbos. Journal of Applied Ecology 28, 1-15.

Yelenik, S.G., Stock, W.D. and Richardson, D.M. 2004: Ecosystem level impacts of invasive Acacia saligna in the South African fynbos. Restoration Ecology 12, 44-51.

Yurkonis, K.A. and Meiners, S.J. 2004: Invasion impacts local species turnover in a successional system. Ecology Letters 7, 764-69. 